\title{
ORGANIZATIONAL ANTECEDENTS TO DESIGNING A COMPREHENSIVE COMPLAINT MANAGEMENT SYSTEM
}

Associate Professor of Marketing, University of Valladolid ANA ISABEL RODRÍGUEZ-ESCUDERO

Professor of Marketing, University of Valladolid

JAVIER RODRÍGUEZ-PINTO*

Associate Professor of Marketing, University of Valladolid

\section{* Corresponding author:}

Address: Facultad de Ciencias Económicas y Empresariales, Avda. Valle Esgueva 6, 47011 Valladolid, Spain.

Telephone: +34983184569 Fax: +34983423899

Email: javierrp@eco.uva.es

\begin{abstract}
:
The literature highlights two main approaches to designing an effective complaint management system: the mechanistic and the organic. The mechanistic approach emphasizes the establishment of guidelines for the correct processing, attention and resolution of complaints received. In contrast, the organic approach relies on creating a supportive internal environment for correct customer attention, made possible through training and empowering employees responsible for complaint management and by promoting extra-role behaviour among them. The present research aims to study the antecedents of adopting these two approaches. From a strategic perspective, we analyse the influence of organizational culture variables (the extent to which the firm is customer- and innovation-oriented) and the nature of the objectives pursued by complaint handling (defensive vs. improvement objectives). The proposed model is tested on a sample of 140 manufacturing firms. Findings indicate these antecedents shape the complaint management system in a very differing and significant manner.
\end{abstract}

\section{Keywords:}

Complaint management, organizational culture, organizational behaviour, innovation and R\&D

\section{Acknowledgements.}

The authors wish to thank the financial support of the Junta de Castilla y León (Spain), project references VA112P17 and VA085G18, and the Ministerio de Economía, Industria y Competitividad, project reference ECO2017-86628-P. 


\section{ORGANIZATIONAL ANTECEDENTS TO}

\section{DESIGNING A COMPREHENSIVE COMPLAINT}

\section{MANAGEMENT SYSTEM}

\section{Introduction}

In the present economic and business context characterized by ever increasing competition, maturing industries and contracting markets, it is becoming increasingly difficult for marketing to achieve its traditional attack objectives, namely attracting new customers, promoting a new brand and securing increased purchase frequency. In this context, companies need to revise their strategies and focus their efforts on customer satisfaction and loyalty. Complaint management plays a key role in any such strategies (Halbheer, Gärtner, Gerstner \& Koenigsberg 2018). In this regard, academic literature advocates two kinds of management approach, the mechanistic and the organic (Kessler, Nixon \& Nord, 2017) when setting up a comprehensive complaint management system able to improve customer perception of justice and generate future economic benefits for the company by recovering customer satisfaction and gaining loyalty (Homburg \& Fürst, 2005; Orsingher, Valentini \& Angelis, 2010; Van Vaerenbergh \& Orsingher, 2016).

The mechanistic approach to complaint handling is based on implementing rules, strictly defined tasks, times and protocols of action aimed at enabling the efficient and consistent resolution of customers' complaints. Complaints are frequently deemed to be an embarrassing situation causing stress and activating defensive behaviours (e.g., discouraging customers from complaining, hostile responses, no transmission or biased transmission to managers, lack of analysis...), which act as a barrier to their effective handling (Homburg \& Fürst, 2007). Adequate guidelines and protocols help to prevent or reduce such defensive behaviour. In this way, the quality of the guidelines set out by the company for processing complaints, interacting with complaining customers and providing them with compensation will determine customer justice evaluations (Homburg \& Fürst, 2005; Homburg, Fürst \& Koschate, 
2010).

In clear contrast to the mechanistic approach, the organic approach has also been suggested as an appropriate organizational system leading to effective and successful complaint management (Maxham \& Netemeyer, 2003; La \& Kandampully, 2004). Under this approach, decision making is not based on a vertical structure of hierarchical control, but rather it is the employees themselves who are enabled to redefine and adapt their role and responses to the context. Implementing an organic approach allows for a flexible complaint management system by providing employees and complaint managers with solid education, and promoting team working and smooth interpersonal relationships. Such an approach creates a supportive climate, fosters greater commitment to satisfying customer needs, and leads to a better alignment of employees' motivations and behaviours with the internal and external demands.

Yet despite the many works in the field of complaint management, there are still issues that academic literature has failed to provide a consistent answer to. For instance, how can firms establish an effective and efficient complaint management system? How can management foster the adoption of a mechanistic and organic approach? In other words, there is a need to explain the organizational antecedents of a comprehensive complaint management system (Van Vaerenberg \& Orsingher, 2016). In order to understand how companies adopt both approaches to improve the performance of the complaint management system, the present study explores how specific organizational antecedents can act by increasing or weakening the application of the mechanistic and organic approaches in complaint handling. In particular, an analysis is carried out of the importance which company culture (more specifically the firm's customer orientation and innovation orientation) and the nature of the complaint management objectives (i.e., defensive and/or improvement) have as a starting point when designing a comprehensive complaint management system. Scholarly research in this field has yet to focus on these potential antecedents. In contrast to most studies, this study proposes that going beyond merely seeking a quick and satisfactory response and explicitly seeking opportunities to learn from complaints and improve product offerings can help to achieve effective complaint management.

In this research approach, company culture is the starting variable when designing the complaint 
management system, since it provides an action framework through which the firm's relations with its environment are developed (Smircich, 1983). Despite the numerous definitions of organizational culture (Schein, 1992; Kotler \& Heskett, 1992; Barney, 2001), underlying all of them is the idea concerning the need to generate shared values, beliefs and attitudes amongst the members of the organization so as to competitively guide the company's efforts when it socially and economically interacts with the environment where it engages in its activity. In market economies it has become particularly common nowadays for firms to adopt a market orientation and an innovation orientation approach as the right organizational culture to face current demands (Homburg \& Pflesser, 2000; Narver, Slater \& MacLachlan, 2004; Siguaw, Simpson \& Enz, 2006).

A culture that is open to the market and an innovative profile in a company are reflected by setting specific management objectives (Cameron \& Quinn, 1999). The key motivation underlying such objectives is firm competitiveness (Van Vaerenberg \& Orsingher, 2016). Companies are clearly concerned with reacting efficiently to the complaints received so as to restore customer satisfaction (Davidow, 2003; Orsingher et al., 2010). This is the most common motivation when designing a complaint management system. What is less common is for firms to perceive complaints as a means of obtaining relevant information vis-à-vis securing future improvements (Santos-Vijande, Díaz-Martín, Suárez-Álvarez \& Del Río-Lanza, 2013; Yilmaz, Varnali \& Kasnakoglu, 2016). Bearing both concerns in mind, two specific kinds of objectives are established; firstly, so-called commercial or defensive goals, and secondly the improvement objectives as antecedents of the complaint management system.

In addition to this contribution, the present research differs from current literature in two ways. Firstly, the study is approached from the company perspective. Apart from a few exceptions -such as Tax and Brown (1998), Homburg and Fürst $(2005,2007)$ or Santos-Vijande et al. (2013)-, research into complaint handling has mainly been conducted from the customer perspective only (e.g., Blodgett, Granbois \& Walters,1993; Tax, Brown \& Chandrashekaran, 1998; Smith, Bolton \& Wagner, 1999; Saxby, Tat \& Johansen, 2000; Del Río-Lanza, Vázquez-Casielles \& Díaz-Martín, 2009; Harun, Rokonuzzaman, Prybutok \& Prybutok, 2018). Secondly, a study is made of complaint management in 
manufacturing companies and the proposed model is tested on a representative sample covering multiple industries. Such an approach is yet to figure prominently in complaint handling research, which is mainly based on specific industries and the service sector (Vos, Huitema \& De Lange-Ros, 2008). Services display two key features that account for why most research studies have opted to analyse this particular sector. The first is the inseparability of production and consumption, which leads to a high degree of interaction between customers and employees (Grönroos, 1978) meaning that the latter need to be more trained to respond quickly and efficiently when a problem emerges. The second, the greater likelihood of heterogeneity in the provision of services, means that the perception of risk of service failure increases. In the area of manufacturing companies, however, far less scholarly research has been conducted into complaint management, despite the fact that for manufacturers of industrial products and consumer products alike, it might be of great interest. In the former case, this is because industrial customers often need a product tailored to their business, which leads to greater diversity in the sales and production processes, in turn increasing the likelihood of failure as it is more difficult to guarantee consistent quality when processes are customer specific and cannot be standardised. In the case of consumer product manufacturers, this is because they mostly work with indirect distribution channels (Anderson \& Narus, 1990) and, therefore, are not directly aware of consumer opinion at a time when, given the growing power of the large distribution companies (Lindblom \& Olkkonen, 2006), consumer product manufacturers should be particularly concerned with not surrendering full control over the sale of their products and should be keen to understand the "voice of end users".

\section{Research proposal}

\section{Antecedents of the complaint management system}

The starting point in the design of the complaint management system is company culture. Nowadays, the literature assumes that in order to survive and maintain a sustainable competitive advantage in the market, companies need to adopt an organizational culture in which two types of orientation should be prevalent: customer orientation and innovation orientation (Homburg \& Pflesser, 2000; Narver et al., 2004; Siguaw et al., 2006). In market economies, market orientation has become common as an 
organizational culture crucial to meeting current marketplace challenges and requirements (Kumar, Jones, Venkatesan \& Leon, 2011). A central component of market orientation -obviously the most relevant in the context of complaint handling- is customer orientation (Narver \& Slater, 1990). A customer-oriented company is alert to and conscious of evolving consumer needs and builds upon a thorough knowledge and understanding of these needs in order to create attractive commercial offers that provide superior value (Blocker, Flint, Myers \& Slater, 2011; Kohli \& Jaworski, 1990; Narver \& Slater, 1990). As a result, the very nature of customer relationship management demands that greater attention be focused on understanding and anticipating customers' current and latent needs, even more so when aiming to efficiently handle customers’ complaints (Homburg \& Furst, 2005).

Furthermore, innovation orientation, understood as a knowledge structure that guides all the organizational strategies and actions to promote innovative thinking and successful innovations, proves essential when competing in today's dynamic and competitive markets (Siguaw et al., 2006). Forms of innovation can be associated with both innovation in products, processes and technology as well as with the creative and innovative capacity of frontline personnel enabling a richer contribution of their knowledge, attitudes and behaviours (Gielis, Schepers, Nijssen \& Ordanini, 2013). In sum, innovation orientation is conceived as a knowledge structure that demands changes in the organizational system as a whole, given that the notion of staying open to new ideas is one aspect of company culture (Hurley \& Hult, 1998).

Customer orientation, in other words, identifying and using information from actual and potential customers, differs conceptually from innovation orientation. Customer orientation is an outside-in process and is a resource that creates superior value (Blocker et al., 2011). Innovation orientation is an inside-out process (Narver et al., 2004) whose origin might or might not be information from the consumer. Both dimensions of company culture provide the firm with complementary values. Nevertheless, the two perspectives might be related. The idea that customer orientation is an antecedent of innovation orientation is widely accepted, as evidenced by the meta-analyses of Kirca, Jayachandran \& Bearden (2005) and Grinstein (2008).

Company culture shapes the setting out of specific objectives of complaint handling. It would seem 
reasonable to assume, and indeed some studies have shown it to be so (e.g., Wirtz \& Mattila, 2004), that companies are mainly concerned with reacting efficiently to grievances and complaints, providing quick and fair responses and compensation which restores satisfaction and reduces customer churn in order to meet the firm's commercial goals. Thus, defensive objectives in complaint handling are preeminent in many companies. For decades, the main concern of those responsible for the complaint system has been avoiding the loss of customers resulting from an error attributable to the company, which explains the academic focus on gauging the impact that failures and the corresponding recovery strategies might exert on customers’ justice, satisfaction, and behavioural assessments (e.g., Fornell \& Wernerfelt, 1988; Smith et al., 1999, Davidow 2000, Orsingher et al., 2010). However, restoring satisfaction and reducing customer churn is not the only goal to be expected from the complaint management system. The system can also nurture organizations with key information concerning the reasons why complaints occurred, thus providing valuable insights for future improvement projects (Vos et al., 2008; Santos-Vijante et al., 2013). Establishing improvement objectives involves adopting a broader -more strategic and not only operational- view of complaint handling which extends the analysis towards the preliminary and subsequent stages of the mistakes made (La \& Kandampully, 2004). The aim is to evaluate all the information that derives from complaints in an effort to ascertain the true causes so as to learn from the mistakes, gauging how satisfied customers are with the solution offered in order to provide feedback to the process with improvements in products, services or customer relations (Tax \& Brown, 1998, Vos et al., 2008, Santos-Vijande et al., 2013, Knox \& van Oest, 2014). The relative focus on one or another type of objectives condition the approach mechanistic or organic- adopted in complaint handling.

\section{Approaches in the design of the complaint management system}

A firm's complaint management system is a key strategic element aimed at dealing with and solving complaints received from customers. Developing a complaint management system requires an organizational structure which helps to ensure that results are obtained that prove satisfactory to both parties involved in the commercial relationship; customer and firm. Based on the Burns \& Stalker (1961) theory of organic/mechanistic structures, combining the two structures or approaches when 
setting up the complaint management system enhances firm performance (Homburg \& Fürst, 2005).

The mechanistic approach reflects the notion that establishing protocols and guidelines in order to design and organize tasks can help employees act in a more disciplined manner and can improve their attention towards the activities they must engage in on a daily basis. Particularly, there are three types of guidelines in the proposed model: procedural, behavioural and outcome guidelines. Procedural guidelines deal with the existence of formal and consistent organizational procedures for registering, processing and resolving customer complaints (Homburg \& Fürst, 2005). These guidelines range from making available to the customer the various services and channels for receiving the complaint to recording and processing customer complaints and by making customer involvement in processing and dealing with the complaint possible. The present proposal considers four variables as constituents of procedural guidelines: facilitation (Goodwin \& Ross, 1992; Blodgett, Hill \& Tax, 1997; Davidow, 2003), processing protocol (Conlon \& Murray, 1996; Smith et al., 1999; Davidow, 2000), customer participation in the process (Lind \& Tyler, 1988; Saxby et al., 2000; Homburg et al., 2010) and in the resolution (Heide \& John, 1992; Tax et al., 1998; Smith et al., 1999). As for behavioural guidelines, these norms guide employee behaviour in their interactions with complainants so as to ensure that appropriate personal treatment and relevant information concerning the complaint in question are provided. Based on this definition, two dimensions are considered within this type of norm: interpersonal treatment of the customer (Estelami, 2000; McCollough, Berry \& Yadav, 2000; Davidow, 2003) and the level of explanation the company gives the customer (Greenberg, 1990; Conlon \& Murray, 1996; Davidow, 2003). Outcome guidelines refer to both the financial or nonfinancial compensation that the company might award the customer for the damage caused. The explanation given to customers -defined as a behavioural norm-, often proves insufficient to maintain and regain their trust. In this research context, outcome guidelines are defined by two dimensions: apology (Hoffman, Kelley \& Rotalsky, 1995; Webster \& Sundaram, 1998; Smith et al., 1999) and redress (Hoffman et al., 1995; Davidow, 2003; Kwon \& Jang, 2012).

Finally, under the term organic approach, the human resources practices aimed at training, motivating and satisfying employees' needs so that they are able to solve customers' complaints in an effective 
manner is assessed. Rather than establishing exhaustive rules concerning how employees should behave in each situation, the organic approach relies on providing shared values that can guide their behaviour so that it is consistent with these values and with the organization's objectives (Homburg \& Fürst, 2005). This approach is suited to creating an internal environment that is favourable to complaint handling by improving the quality of the employment relationship (Crone, Carey \& Dowling, 2003). Three dimensions of the organic approach are focused on here: those concerning training and empowering employees, and promoting extra-role behaviours among them. Training is seen as a process in which employees acquire abilities and job skills to adequately deal with conflictive and stressful encounters with customers, the objective being to share the organization's norms and values. The aim is to improve their ability to find an optimal and sometimes unique solution to customer complaints (Hart, Heskett \& Sasser, 1990). Empowerment refers to the decisionmaking capacity of the personnel who are in direct contact with customers. This implies major employee flexibility, endowing them with far more autonomy, responsibility and the authority needed to act and to have access to resources in their prevention and recovery strategies (Hart et al., 1990; Chebat \& Kollias, 2000; Kwak \& Jackson, 2015). The extra-role behaviours of frontline employees and complaint managers are a kind of outperformance or discretional behaviour that, as a consequence of a high motivation and commitment, goes beyond the requirements of their function or formal role in the organization (Bettencourt \& Brown, 1997). Being in touch with customers and complainants frequently requires emotional intelligence and deep acting to anticipate problems and solutions (Nsenduluka \& Shee, 2009; Kim, Hur, Moon \& Jun, 2017).

\section{Model and hypotheses}

As mentioned in the introduction, the proposed model seeks to explain the importance of company culture and the objectives of complaint handling when designing a complaint handling system characterized by the adoption of mechanistic and organic approaches (Figure 1). In particular, the proposal is that the company culture influences the kind of objectives established $\left(\mathrm{H}_{\mathrm{I}}\right)$, and the type of objectives influences the mechanistic $\left(\mathrm{H}_{\text {II }}\right)$ and organic $\left(\mathrm{H}_{\text {III }}\right)$ approaches. There is also conjectured to be a direct effect of company culture on the organic approach $\left(\mathrm{H}_{\mathrm{IV}}\right)$. Finally, even when not 
formulating a hypothesis, the possible positive influence of customer orientation on innovation orientation is examined. Both orientations -customer and innovation- are complementary and may be interrelated. To achieve a customer-oriented company goal of creating competitive and high-value commercial offers for the customer, it is necessary to innovate in products as well as processes. Customer orientation will serve to stimulate favourable attitudes towards innovation that will entail an organizational learning philosophy (Siguaw et al., 2006). The literature widely supports the existence of a relationship between market orientation and innovation orientation (Kirca et al., 2005; Grinstein, 2008), although existing research on this relationship has not dealt with the area of complaint handling.

(Insert Figure 1 here)

\section{The effect of company culture on the objectives of the complaint management system $\left(\mathrm{H}_{\mathrm{I}}\right)$}

There is abundant literature on customer orientation as a business philosophy which holds that identifying and satisfying customers' needs should be a core company priority (Blocker et al., 2011; Narver \& Slater, 1990). It seems reasonable to assume that the more customer-oriented a company is, the greater importance it will attach to correctly handling complaints as a source of knowledge. Insofar as being customer-oriented entails continuously and rigorously evaluating and monitoring customer satisfaction, the complaints system will need to deal efficiently with customers' grievances, adopting the pertinent corrective measures so as to regain their satisfaction, maintain customer loyalty and even attain additional purchases and favourable recommendations (Tax et al., 1998, Davidow, 2000, Wirtz \& Mattila, 2004). To that end, organizations must undertake efficient recovery strategies in terms of speed when complaints are to be answered (Johnston \& Mehra, 2002), offering a kind response (Estelami, 2000) and fair compensation (Fornell \& Wernerfelt, 1988), thus avoiding or decreasing the possible loss of dissatisfied customers. The following hypothesis is thus stated:

Hypothesis I.1a. The company's customer orientation encourages the establishment of defensive objectives for complaint handling.

Customer orientation also seeks to boost innovation and ongoing improvement so as to achieve 
sustainable competitive advantage. From a proactive perspective of customer orientation, companies attempt to anticipate market requirements and also to embrace solutions that consumers are yet to envisage (Blocker et al., 2011; Narver et al., 2004). In the field of failure management, being aware of customers' perceptions, pinpointing the causes of their dissatisfaction, as well as changes in likes and preferences is assumed to be important since these will prove a valuable source of information for improving all the company's processes and products. Thus, a customer-oriented company is one that is concerned with value creation and is sensitive to new business opportunities which may emerge and to identify which it is necessary to draw on the right market intelligence and learning capacity (Kohli \& Jaworski, 1990). This way of thinking, used in complaint management, is reflected in the aims and objectives of the complaint management system, which seeks constant improvement from the lessons learnt when dealing with complaints (Smith \& Bolton, 1998, Homburg \& Fürst, 2007, Santos-Vijande et al., 2013). It can thus be said that emphasizing the improvement aims of the complaint management system is a natural implication of a customer-oriented company, since it not only seeks to provide an efficient service for customers' present and future requirements, but also to improve processes (Tax \& Brown, 1998; Johnston, 2001), learn from mistakes and develop quality relationships with customers (Vos et al., 2008). Accordingly, it is hypothesized that:

Hypothesis I.1b. The company's customer orientation encourages the establishment of improvement objectives for complaint handling.

From the field of complaint handling, companies with an innovation-oriented culture conceive complaints as opportunities for improving the management and development of new products and services (La \& Kandampully, 2004, Vos et al. 2008). Using this perspective, it can be claimed that companies' innovation strategies determine the philosophy of complaint handling processes to the extent that they place less emphasis to purely operational aspects, lend greater attention to contextual changes and long-term relationships with customers, and persistently pursue competitive advantage in the market. It can thus be argued that innovation orientation predisposes a company towards establishing improvement objectives in all of its areas (Siguaw et al., 2006), particularly in complaint handling, heightening its capacity for recovery (Hart et al., 1990), making it more conscious of the 
importance of learning from failures in products and services and mistakes in customer relationship management (Santos-Vijande et al., 2013; Tax et al., 1998), and promoting the integration of complaint processing activities into new product development processes (Vos et al., 2008). Thus, the proposal is that:

Hypothesis I.2. The company's innovation orientation encourages the establishment of improvement objectives for complaint handling.

\section{The effect of the complaint management system objectives on the mechanistic approach ( $\left.\mathrm{H}_{\text {II }}\right)$}

The mechanistic approach, which advocates setting standards for achieving efficient behaviour, is fully consistent with a reactive or defensive view of complaint handling. When objectives are more defensive -correcting errors and decreasing customer loss- the organization should be involved in operating aspects of complaint handling such as offering different channels for receiving complaints, guaranteeing smooth processing and enabling the customer to give details of the problem and the expected solutions (Gielis et al., 2013; La \& Kandampully, 2004). In this context, it makes sense to rely on establishing guidelines, protocols and routines as a basis for a system to react quickly to failures and to meet the challenge of recouping the satisfaction of customers who have suffered such failures (Homburg \& Fürst, 2005; Homburg et al., 2010). It is therefore conjectured that:

Hypothesis II.1. The defensive objectives of the complaint management system have a positive influence on the adoption of a mechanistic approach through guidelines for: (a) facilitation, (b) processing protocol, (c) customer participation in the process and (d) in the solution, (e) interpersonal treatment, $(f)$ explanation, $(g)$ apology and $(h)$ redress.

Improvement objectives are also felt to influence the variables in the mechanistic approach in that complaints become critical input to organizational learning. Although it has another purpose, which differs from the defensive objective, a correctly functioning complaint management system still proves important, in this case vis-à-vis ensuring that the company gains information from the customers themselves about the failures made. Establishing appropriate procedural guidelines is thus key to making sure that customers are given every opportunity to present their complaint and the chance to 
explain the problem in detail and how it might be dealt with. This valuable information is recorded and can be used to innovate and improve the company. Yet it should not be forgotten that a good complaint management process, in addition to having clear procedures for both complainant and company alike, must provide a quick response, since the basic aim of the system is to solve the complaints received (Johnston, 2001; Vos et al., 2008). This is why it may be felt that both appropriate behavioural and outcome guidelines will prove useful for achieving learning, since fluent dialogue is required with the customer throughout the process and after the problem is solved in order to gain a global view of the possible causes of the problem and of which of the organization's responses have led to improved performance. In short, the mechanistic approach must be at the service of the improvement objectives so that employees may work systematically in the search for new and better solutions to the problems posed by customers. This leads to the following hypothesis:

Hypothesis II.2. The improvement objectives of the complaint management system have a positive influence on the adoption of a mechanistic approach through guidelines for: (a) facilitation, (b) processing protocol, (c) customer participation in the process and (d) in the solution, (e) interpersonal treatment, $(f)$ explanation, $(g)$ apology and $(h)$ redress.

\section{The effect of the complaint management system objectives on the organic approach $\left(\mathrm{H}_{\text {III }}\right)$}

In order to effectively fulfil the defensive objectives of the complaint management system, the company requires skilled human resources. Considering that working and interacting with dissatisfied customers is neither easy nor pleasant (Homburg \& Fürst, 2007), companies develop specific training programmes designed to instruct their employees in how to behave in conflict situations with customers. Both formal training as well as training in organizational values (Maxham \& Netemeyer, 2003) respond to the defensive objectives for failure recovery in an effort to avoid losing customers who are dissatisfied with the products purchased.

Consequently, establishing defensive objectives in complaint management encourages greater commitment to the organic approach insofar as the results of the system and the correct application of the rules depend on the skills and abilities of the employees responsible for complaint handling, placing the emphasis on training, on increasing autonomy and on developing extra-role behaviours so 
as to restore customer satisfaction and loyalty. The following hypothesis is thus proposed:

Hypothesis III.1. The defensive objectives of the complaint management system have a positive influence on the adoption of an organic approach through (a) training and (b) empowering employees and (c) fostering among them extra-role behaviour.

The current business environment requires going beyond purely defensive or reactive objectives and stresses the need to envisage a long-term strategic view of complaints management. Well-trained and motivated employees will not merely confine themselves to correcting failures but will contribute to creating a knowledge base that will prove extremely useful to the company in its ongoing innovation and transformation process (La \& Kandampully, 2004). Therefore, when complaint handling is viewed as an opportunity to nurture improvement processes it is necessary to increase flexibility and ensure that human resource efforts go beyond mere knowledge and take on greater autonomy and become proactive or extra-role behaviours. Empowering helps the organization to learn and improve. Empowered employees are often more alert to feedback from customers since it is important to make correct decisions, decisions for which they feel responsible thanks to empowerment (Chebat \& Kollias, 2000). In short, the need to adapt the human resources structure to the strategy of improvement and innovation makes the improvement objectives of complaint handling an antecedent of the organic approach, which relies on developing a more proactive orientation of the organization's soft factors. Based on an exhaustive analysis of mistakes, this proactiveness is geared towards preventing these mistakes from occurring again and finding novel solutions to improve products, processes and relationships with customers. The above leads to the following hypothesis:

Hypothesis III.2. The improvement objectives of the complaint management system have a positive influence on the adoption of an organic approach through (a) training and (b) empowering employees and (c) fostering extra-role behaviour among them.

\section{The effect of company culture on the organic approach $\left(\mathrm{H}_{I V}\right)$}

In their seminal article on market orientation, Kohli \& Jaworski (1990) explained the psychological and social benefits for employees to derive from market orientation. Workers in more market-oriented 
companies feel prouder of belonging to the company, are more committed and satisfied with their work and are more sensitive to customers' needs. Innovation orientation also involves strategic implications that affect various organizational areas, including human resources. An innovationoriented company requires human capital that also values learning, change or creativity and that is willing to take risks and assume responsibilities. Siguaw et al. (2006) postulate that firms with a strong innovation orientation are more likely to implement formal and informal policies and practices that encourage and support employee action towards innovation. It therefore seems reasonable to consider the potential positive direct effects of customer orientation and innovation orientation on training, empowerment and encouragement of extra-role behaviour among employees involved in complaint handling. It is thus hypothesized that:

Hypothesis IV.1. The company's customer orientation has a positive influence on the adoption of an organic approach through (a) training, (b) empowering employees and (c) fostering extra-role behaviour among them.

Hypothesis IV.2. The company's innovation orientation has a positive influence on the adoption of an organic approach through (a) training, (b) empowering employees and (c) fostering extra-role behaviour among them.

\section{Methodology}

\section{Data gathering and sample}

Based on the Amadeus database, 2,536 Spanish companies with more than 50 employees belonging to different manufacturing sectors were selected as the population universe -see Table1. Drawing on a large and varied number of sectors has the advantage of making it possible to generalize the findings beyond the uniqueness that might be attributed to some of them. The minimum of 50 employees required for a company to be included in the population was set considering that it may be difficult for smaller companies to have a standardised procedure and to provide information on certain variables in the model.

For data collection, a questionnaire was used which was pre-tested with five manufacturing industry 
managers as well as the head of the contact centre division of an integral marketing services company. The questionnaire was sent via postal mail to all the companies in the population universe together with a cover letter explaining the study and a website address for those who preferred to fill out the questionnaire online. The cover letter was addressed to the marketing manager, although it was pointed out that the questionnaire should be filled in by the head of complaint handling at the company. After a number of phone calls (approximately 900) aimed at increasing participation, 140 valid surveys were finally received.

\section{Sample representativeness and data quality}

To assess sample representativeness, two variables were used: industry type and number of employees. As regards the industry, Table 1 displays absolute and relative statistics for the population universe and the sample. The proportion test reveals the non-existence of significant differences, reflecting that the composition of the sample is similar to the population being surveyed. In addition, a means difference test using Amadeus data showed that the number of employees in companies answering the questionnaire did not differ significantly from the population average. This even holds for each industry, with the sole exception of the group of companies competing in chemical, natural rubber and plastic materials industries ${ }^{1}$. Overall, the sample can be deemed representative of the population of companies whose complaint handling behaviour the present research sought to study.

\section{(Table 1 here)}

Armstrong \& Overton's (1977) procedure was used to assess non-response bias. Analysis of variance showed that the answers to the questions concerning the variables in the model given by early and late respondents were similar. Only for one of the items measuring customer participation in the solution was a significant difference at the $5 \%$ level observed (the average score given to this item by early respondents was significantly higher). It was therefore concluded that non-response bias is not a major

\footnotetext{
${ }^{1}$ For this group of industries, firms in the sample seem to have a significantly larger workforce. However, this is due to the fact that the sample includes the company which employs by far the largest workforce of all those in these industries. This obviously dramatically increases the average number of employees in the sample. If this company were excluded, the average number of employees in the sample would fall to 192, with a standard deviation of 298, and the $z$ statistic would be -.40 , which leads to the conclusion that companies in the sample in these sectors do not significantly differ in size from the population they represent.
} 
problem in the sample.

Given that in each company a single informant answered all the survey questions, steps were taken to ensure that common method bias (CMB) is not an important issue in this investigation. Following Podsakoff, Mackenzie, Lee \& Podsakoff's (2003) recommendation, an effort was made a priori to reduce common method variance (CMV) through careful design of the questionnaire wherein item wording was thoroughly revised so as to prevent biased connotations and where the order of the questions was dissimilar to the sequence of cause-effect relationships specified in the model. In addition, Harman's one-factor test (Podsakoff \& Organ, 1986) was applied. Exploratory factor analysis with all the items in the model resulted in 12 factors with an eigenvalue greater than one explaining $75.3 \%$ of total variance, with the first factor explaining only $29.9 \%$. According to Fuller, Simmering, Atinc, Atinc \& Babin (2016), these results indicate that a large amount of CMV is not observed in the data and, what is more important, it is therefore very unlikely that common method could substantially bias the estimated relationships.

\section{Construct measurement}

As pointed out at the beginning of this study, despite the huge amount of research into complaints handling, very few studies have been conducted from the organizational perspective. Consequently, in this survey it was necessary to make major adaptions to the scales previously used in the literature, which tend to adopt mainly the customer perspective. Table 2 shows the specific items used to measure the constructs in the model. The main papers focused on when devising the measurement instruments used are the studies of Tax et al. (1998), Smith et al. (1999) and Homburg and Fürst (2005). 7-point Likert scales were used, with 1 indicating “disagreement” and 7 "agreement”.

\section{Results}

The proposed model was tested by means of the Partial Least Squares path modelling (PLS) technique using the SmartPLS v.3.2.7 (Ringle, Wende \& Becker, 2015) software. One of the main reasons for using this technique is its capacity to estimate models that include formative constructs and work with moderate size samples, which are significant advantages in this case. The results of the empirical 
research are analysed and interpreted in two steps: assessing the measurement model and the structural model.

\section{Measurement model}

Table 2 shows the main figures of the measurement model of the constructs in the research. It was verified that all factor loadings were greater than .7 and composite reliability (CR) and average variance extracted (AVE) values greater than .7 and .5, respectively, for all the reflective scales (Hair, Hult, Ringle \& Sarstedt, 2017). When validating the formative indices -facilitation and processing protocol- in addition to examining the magnitude and significance of the weight of each indicator in the formation of the corresponding index, it is necessary to rule out multicollinearity issues. As can be seen in Table 2, there is no sign that multicollinearity can affect the results (variance inflation factors, VIF, are clearly below 5, and excessively high correlations are not apparent among the formative indicators). However, some small and non-significant weights are observed. This means the relative contribution of these indicators to the formation of the corresponding index is small, but following the recommendations of Hair et al. (2017), given that their absolute contribution is noticeable (loadings are above .5), these indicators are retained in the specification of the measurement model.

Considering Blocker et al.'s (2011) critical distinction between responsive and proactive customer orientation -in turn inspired by Narver et al.’s (2004) seminal work on proactive market orientationcustomer orientation was specified as a second order reflective-formative construct, that is, as a construct consisting of two components (responsive and proactive customer orientation), each measured with three reflective indicators. Following the recommendations of Hair et al. (2017), the repeated indicators approach was used, and it was verified that the reflective measurement scales of both first-order components were valid and reliable, and that multicollinearity is not an issue when estimating the weight of each component in the formation of the customer orientation second-order construct (VIF is only 1.74). These weights are .49 for responsive customer orientation and .61 for proactive customer orientation, and both are significant $(\mathrm{p}<.01)$.

(Table 2 here) 
Finally, the discriminant validity of the set of constructs was assessed (see Table 3). Following Fornell and Larcker's (1981) procedure, for each reflective construct the square root of its AVE was seen to be greater than its correlation with any other construct and cross-loadings were also examined. In addition, the criterion recently proposed by Henseler, Ringle \& Sarstedt (2015) was applied. This is based on the HTMT (heterotrait-monotrait) ratio of correlations, and these ratios should not exceed the threshold of .85, which is indicative of lack of discriminant validity. As shown in Table 3, all the HTMT ratios satisfy this condition, thus providing rigorous evidence of the discriminant validity of all the reflective constructs in the model.

(Table 3 here)

\section{Structural model}

Table 4 shows the standardized coefficients of the model tested. First, results support the hypotheses concerning the effects of company culture on the objectives of the complaint management system. Customer orientation has a positive and significant effect on both types of objectives, defensive $\left(\mathrm{H}_{\mathrm{I} .1 \mathrm{a}}\right.$ : $\beta=.31, \mathrm{p}<.01)$ and improvement objectives $\left(\mathrm{H}_{\mathrm{I} .1 \mathrm{~b}}: \beta=.27, \mathrm{p}<.01\right)$. The hypothesis concerning the positive influence of innovation orientation on improvement objectives is likewise supported $\left(\mathrm{H}_{\mathrm{I} .2}: \beta=\right.$ $.33, \mathrm{p}<.01)$. Given the significant relationship observed between customer orientation and innovation orientation $(\beta=.41, \mathrm{p}<.01)$, customer orientation was also found to influence improvement objectives indirectly, via innovation orientation (indirect effect $=.13, \mathrm{p}<.01$ ).

The positive influence of defensive objectives on the processing protocol $\left(\mathrm{H}_{\text {II.1b }}: \beta=.36, \mathrm{p}<.01\right)$, customer participation in the process $\left(\mathrm{H}_{\text {II.1c }}: \beta=.33, \mathrm{p}<.01\right)$ and the solution $\left(\mathrm{H}_{\text {II.1d: }} \beta=.24, \mathrm{p}<.01\right)$, interpersonal treatment $\left(\mathrm{H}_{\text {II.1e }}: \beta=.41, \mathrm{p}<.01\right)$, explanation $\left(\mathrm{H}_{\text {II.1f: }} \beta=.32, \mathrm{p}<.01\right)$ and apology $\left(\mathrm{H}_{\mathrm{II.1g}}: \beta=.22, \mathrm{p}<.01\right)$ is also borne out. However, no significant influence of defensive objectives on facilitation ( $\mathrm{H}_{\text {II.1a: }} \beta=.04$, n.s.) and redress were found ( $\mathrm{H}_{\mathrm{II} .1 \mathrm{~h}}: \beta=.04$, n.s.).

As regards improvement objectives, data support all the hypotheses concerning the effect that establishing this type of objective has on the different variables in the mechanistic approach: facilitation ( $\left.\mathrm{H}_{\text {II.2a }}: \beta=.47, \mathrm{p}<.01\right)$, processing protocol $\left(\mathrm{H}_{\text {II.2b: }}: \beta=.29, \mathrm{p}<.01\right)$, customer participation 
in the process $\left(\mathrm{H}_{\mathrm{II} .2 \mathrm{c}}: \beta=.23, \mathrm{p}<.01\right)$ and the solution $\left(\mathrm{H}_{\mathrm{II} .2 \mathrm{~d}}: \beta=.29, \mathrm{p}<.01\right)$, interpersonal treatment $\left(\mathrm{H}_{\text {II.2e: }} \beta=.19, \mathrm{p}<.05\right)$, explanation $\left(\mathrm{H}_{\text {II.2f: }} \beta=.26, \mathrm{p}<.01\right)$, apology $\left(\mathrm{H}_{\text {II.2g }}: \beta=.48, \mathrm{p}<.01\right)$ and redress $\left(\mathrm{H}_{\text {II.2h: }} \beta=.21, \mathrm{p}<.01\right)$.

Defensive objectives are not found to be significantly related to any of the variables in the organic approach ( $\mathrm{H}_{\text {III.1a: }} \beta=.07$, n.s.; $\mathrm{H}_{\text {III.1b }} \beta=.10$, n.s.; and $\mathrm{H}_{\text {III.1c }}: \beta=.07$, n.s., respectively). In contrast, improvement objectives are seen to drive the company to seek greater training for its employees $\left(\mathrm{H}_{\text {III.2a }}: \beta=.25, \mathrm{p}<.01\right)$, to provide them with greater empowerment $\left(\mathrm{H}_{\text {III.2b: }} \beta=.19, \mathrm{p}<.05\right)$ and to encourage behaviour that goes beyond their formal and expected role $\left(H_{\text {III.2c: }} \beta=.25\right.$, $\left.p<.01\right)$.

Finally, with regard to the fourth block of hypotheses concerning the existence of a direct and positive effect of company culture variables on the organic approach, it was found that customer orientation has a direct impact on the organic approach variables. PLS results show significant coefficients for training $\left(\mathrm{H}_{\mathrm{IV} .1 \mathrm{a}}: \beta=.35, \mathrm{p}<.01\right)$, empowerment $\left(\mathrm{H}_{\mathrm{IV} .1 \mathrm{lb}} \beta=.22, \mathrm{p}<.01\right)$ and extra-role behaviors $\left(\mathrm{H}_{\mathrm{IV} .1 \mathrm{c}}: \beta=.28, \mathrm{p}<.01\right)$. Moreover, significant indirect effects on empowerment $(.15, \mathrm{p}<.01)$ and extra-role behaviour $(.14, \mathrm{p}<.01)$ are observed, which should be added to the positive direct effects. With regard to the hypotheses linking innovation orientation to the organic approach $\left(\mathrm{H}_{\mathrm{IV} .2}\right)$, results reveal there is no direct significant influence on training $\left(\mathrm{H}_{\mathrm{IV} .2 \mathrm{a}}: \beta=-.07\right.$, n.s.), empowerment $\left(\mathrm{H}_{\mathrm{IV} .2 \mathrm{~b}}\right.$ : $\beta$ $=.11$, n.s. $)$ and extra-role behaviour $\left(\mathrm{H}_{\mathrm{IV} .2 \mathrm{c}}: \beta=.05\right.$, n.s. $)$, but that there is an indirect significant effect on said variables $(.08, \mathrm{p}<.05 ; .06, \mathrm{p}<.06 ; .08, \mathrm{p}<.05$, respectively). These findings highlight the mediating role played by the improvement objectives of the complaint system in the relationship between a company's culture and the organic approach variables.

(Table 4 here)

Figure 2 summarizes the empirical results.

(Figure 2 here)

\section{Control variables}

The model was re-estimated including three control variables as antecedents of the components of the mechanistic and organic approaches to clear up any doubts concerning the possibility that rejection or 
acceptance of certain hypotheses might result from errors in model specification. The following variables were included: company size, type of market (B2C vs. B2B) and the use of direct distribution channels. Company size was measured on a 5-point scale where 1 indicates "very small" and 5 "very big". Type of market was determined using the "percentage of sales to consumer markets compared to total company sales”. Finally, applying a dichotomous variable determined whether or not the manufacturing firms in the sample used direct commercial distribution channels.

Verification of the hypotheses was not affected when these control variables were included. In other words, the significance or otherwise of the conjectured relations in the theoretical model remains after having controlled for the size effect, the type of market and whether or not the company uses direct channels ${ }^{2}$. In addition, this new model shows some significant relations concerning certain elements of the two approaches -organic and mechanistic- of the complaint management system. With regard to the size variable, it can be seen that the larger the firm, the less important is the apology variable in the recovery strategy $(\beta=-.13, \mathrm{p}<.05)$. As a means of solving a commercial disagreement, major firms tend to issue an apology to consumers less often, perhaps because they feel it implies they are assuming the blame (Greenberg, 1990), with the subsequent loss of image in the market. As regards the importance of B2C vs. B2B markets, engaging in commercial activity in consumer markets is seen to impact negatively and significantly on variables related to customer participation in the process and in the solution ( $\beta=-.13, \mathrm{p}<.05 ; \beta=-.12, \mathrm{p}<.05$, respectively). In other words, there is less customer participation in solving a complaint when the complaint comes from end users than from industrial customers. Finally, using direct distribution channels is seen to have a significant positive impact on employees' empowerment when handling customers' complaints $(\beta=.16, \mathrm{p}<.05)$. When firms sell directly to customers, cutting out the middle-men, they should empower customer care staff so as to swiftly solve any problems that arise, and provide a solution tailored to the needs of the consumer.

\footnotetext{
${ }^{2}$ For reasons of simplicity, Table 4 shows the results of the model estimation without the control variables. Presenting the results of the model with control variables in this table would mean showing a further 33 relations (11 variables from the mechanistic and organic approaches multiplied by 3 control variables).
} 


\section{Discussion}

Whatever perspective is used to define culture, the literature agrees that it represents a set of values shared by the members of the organization and is a determining factor in employee behaviour, and hence in organizational performance (Schwartz \& Davis, 1981). Successfully designing a complaint management system requires it to be consistent with the values and cultural references prevalent in the organization. In this paper, customer orientation and innovation orientation are deemed essential influences when devising the complaint management system and defining the objectives it pursues. It was conjectured and indeed found to be true that customer orientation motivates both defensive objectives as well as improvement objectives with a strategic learning vision. Customer orientation is therefore a necessary seed when conceiving a comprehensive and competitive complaint management system that pursues more ambitious objectives, and which displays a decided focus on learning and improvement whilst not neglecting the defence and conservation of current customers. A lack of customer orientation no doubt leads to undefined objectives and the absence of any clear complaint handling orientation. In addition, significant positive effects of customer orientation were also found on all the components of the organic approach considered in this study, positive effects which are not only due to the greater emphasis that customer-oriented companies place on improvement objectives. This positive relationship between customer orientation and the organic approach to complaint handling reflects the fact that companies who are deeply-inspired by a culture in which customer satisfaction is a fundamental goal entrust their employees with greater responsibility and discretion in achieving this strategic priority.

As for innovation orientation, findings support the hypothesized positive effect it exerts on the complaint system's improvement objectives, leading to the conclusion that a greater concern for innovation favours the design of the complaint management system as a strategic tool that should help the company to learn from its mistakes and to pinpoint opportunities for improvement and, thus, increase the system's usefulness. That is, companies whose values attach great importance to innovation are more likely to conceive complaint management as a source of ideas and opportunities for improvement in the various organizational areas. This result is hardly surprising given that 
innovation is one of the most important means of achieving competitiveness and enhancing firm performance (Deshpande \& Farley, 2004; Langerak, Hultink \& Robben., 2004). Albeit indirectly, innovation orientation also acts through improvement goals, fostering the development of the organic approach by which human resources acquire a greater capacity and leadership to handle tasks related to customer attention and complaint management.

The present research thus highlights that organizational culture and values condition the objectives established for the complaint management system, which in turn shape the configuration of such a system, in other words, whether it emphasises the mechanistic and organic approaches. Specifically, defensive objectives affect all three types of norms defined from the mechanistic approach -procedural (i.e., processing protocols, customer participation in the process and the solution), behavioural (i.e., treatment and explanation) and outcome guidelines (i.e., apology)-, with the exception of facilitation and redress. These noticeable exceptions in the defensive objectives-mechanistic approach relationship indicate that neither facilitating customers' complaints (i.e., informing them about where, how and to whom they can file a complaint) nor offering redress or compensation for what has happened once the problem has been resolved are central concerns of companies that only seek to restore customer service and avoid losing customers. These findings are consistent with recent research (albeit in the service failure context) showing that service providers rarely conceive the receipt of complaints as a mechanism to strengthen social relationships with customers (Umashankar, Ward \& Dahl, 2017), or demonstrating that moral judgement of failure by complainants may render the company's recovery efforts (e.g., monetary offers and overcompensation) ineffective (Gelbrich \& Roschk, 2011; Chen, Ma, Bian, Zheng \& Devlin, 2018). It is even more noteworthy that a focus on defensive objectives does not seem to have an effect on the organic approach variables. Companies focusing on establishing restoration routines with a defensive purpose steer the complaints management system towards standardized and efficient behaviour. These companies probably do not expect nor do they encourage their human resources to display initiative and proactiveness. Frontline employees and complaint managers are simply required to follow the rules and to meet established standards, without it being strictly necessary for them to be truly motivated and committed to their work. 
Improvement objectives have a broader influence on the configuration of the complaint management system. As do defensive objectives, improvement objectives also impact on mechanistic approach variables. Moreover, unlike defensive objectives, improvement objectives do have a positive and significant effect on all kinds of guidelines, including facilitation and redress. This leads to the conclusion that when the company conceives the complaint system from a learning perspective (Santos-Vijande et al., 2013; Yilmaz et al., 2016), that is, as a strategic tool which proves useful for improvement purposes, it will be willing to work on designing adequate procedural, behavioural and outcome guidelines. This will facilitate and encourage complaints from dissatisfied customers, and even gratify them for the second chance given to correct the mistakes and gain a better understanding of their needs that funnels innovation efforts. In addition, improvement objectives are related to all the components of the organic approach, which was not the case for defensive objectives. The greater the importance attached to improvement objectives, the greater the company's concern for training and empowering its personnel and also for fostering extra-role behaviours amongst team members. It can thus be seen that the resolve to use complaints not only as a defensive mechanism but also as a means to achieve organizational learning and to pinpoint improvement opportunities impacts on the capacity of human resources and on their willingness to engage in behaviour that reaches beyond the company's predetermined path to customer satisfaction. Some time ago, Hart et al. (1990) had already pointed out the need to adopt strategic complaints management -beyond merely standardising procedures- when insisting that firms should train and empower frontline staff to enhance their capacity to anticipate needs for recovery and act fast so as to find an optimal solution.

\section{Conclusions, managerial implications, limitations and future research lines}

Due to its importance in business, complaint management is a topic that has been amply dealt with in recent decades. Most research in this field has been conducted from the customers' perspective, with the focus of interest falling mainly on gaining an insight into the results of firms' service recovery efforts and pinpointing how positive responses can be obtained from customers in terms of their perception of the justice in the solutions provided and their subsequent satisfaction and loyalty (Davidow, 2003; Orsingher et al., 2010; Van Vaerenberg \& Orsingher, 2016). Less attention has been 
paid, however, to exploring complaint management from the company perspective, and a certain bias has been apparent in that the complaint management system has been seen as a defensive mechanism designed to minimise loss of customers and the negative impact that complaints might have for the firm in financial and reputation terms (Homburg \& Fürst, 2007). A growing number of studies are beginning to see complaint management as an opportunity and a means of enhancing products, services and processes achieved through informative learning -registering and analysing complaintsor through interactive learning -based on ongoing communication between individuals in the organization itself and its customers- (e.g., La \& Kandampully, 2004; Vos et al., 2008; SantosVijande et al., 2013; Yilmaz et al., 2016). Nevertheless, the complaint management system needs to be explored in greater depth from a comprehensive standpoint, namely one which embraces the need to merge approaches, preventing complaint management from being based solely on establishing a series of norms and guidelines inherent in a totally mechanistic approach or which, following an extreme organic approach, relies merely on the capacity of human resources to efficiently handle complaints independently and responsibly.

The present research aims to shed light on which organizational factors shape a company's complaint management system. As pointed out, the literature has concerned itself more with examining the benefits and consequences of good or bad management, yet has scarcely explored which drivers determine how the system is designed. This works posits that the extent to which the mechanistic or organic approaches impact on the design of the complaint management system is shaped by the company's prevailing culture and by the nature of the goals pursued when dealing with complaints. The empirical findings show that a greater customer orientation and innovation orientation predispose the organization towards not confining itself to establishing more defensive goals but rather towards seeing complaints as opportunities to improve. Both types of objectives, which are clearly not mutually exclusive, favour the adoption of a mechanistic approach. The findings here, however, reveal that fostering the organic approach will prove complicated if a firm shows little customer and innovation orientation and if it fails to openly signal its desire for ongoing improvement in products and services as a key objective in complaint management. 
As for the main managerial implications, service companies are no doubt keenly aware of the importance of complaint handling, yet manufacturing companies should also embrace values related to customer service and pay careful attention to the systems they use to manage customer complaints. Marketing activities in manufacturing companies are often carried out through indirect distribution channels, which hinders manufacturers' ability to control the product sales process and makes them vulnerable to wholesalers and/or retailers who have ever increasing bargaining power. This makes it particularly important for manufacturing companies to ensure that they concern themselves more with maintaining direct contact with customers and end users, and being present when consumers need help by implementing an efficient complaint management system. In this sense, it is deemed essential for firms to develop a culture in which customer and innovation orientations are prevalent throughout the organization. Such a cultural DNA is, in general, a seed of enhanced competitiveness and, in particular, serves as a solid basis for establishing a superior complaint management system that not only functions as a tactical tool to retain customers, but also as a valuable source of information that benefits innovation processes.

Manufacturers are therefore urged to display an open-minded approach and ambition when designing their complaint management system. This means they should not only concern themselves with restoring customer satisfaction but should also conceive the complaint management system as a powerful lever of innovation to improve the processes and quality of the products offered to customers. It is the will to improve that helps to go beyond mechanistic guidelines (which of course may be necessary and useful for efficient complaint handling) and to take full advantage of the company’s human resources, particularly frontline employees and complaint managers, as they are in a central position to carefully listen to the voice of the customer. These employees should be enabled (through training and empowerment) and should be encouraged to do as much as they can to assist customers, recover their satisfaction and trust, as well as to learn from the mistakes and transmit this knowledge so as to usher in improvements in products and thus avoid future failures.

The main limitation of this paper concerns how the information was collected. The model variables were measured using a single informant: the head of affairs related to customer attention and 
complaint handling. The use of multiple informants, for example other members of the company such as the employees themselves, to measure variables of training, empowerment or extra-role behaviour, would be useful for a more comprehensive measurement of the constructs in the model. Furthermore, the large number of constructs considered has meant having to omit certain situational or contingent variables. Consideration has not been given to the possible role played in the complaints system by the type of problems that lead customers to make their complaints, the severity and variability of their grievances, the type of products involved, to whom responsibility is attributed or the intensity of the firm-customer relationship (Homburg et al., 2010; Donoghue, Strydom, Andrews, Pentecost \& Klerk, 2016). These variables might have a moderating effect on the proposed relationships and, therefore, their absence should be cited as a limitation when drawing conclusions.

Closely related to this, it is clear that the development of the Internet and social networks has radically transformed the way companies and customers interact, with the latter having gained enormous power by being much better informed and with their complaints having far more scope and resonance, thus enabling them to demand accurate and immediate responses from companies (Day, 2011; Ma, Sun \& Kekre, 2015). In this sense, a study focusing on the use of interactive channels for receiving and handling complaints as variables that could intensify or reduce the impact of some of the relationships found in this model might prove enlightening (Breitsohl, Khammash \& Griffiths, 2010).

Finally, as indicated in the literature, the importance that co-creation processes might have in the field of complaint management should also be borne in mind (Heindenreich, Wittkowski, Handrich \& Falk, 2015; Hazée, Van Vaerenbergh \& Armirotto, 2017). Future research could explore how employees, through their experiences when interacting with customers, may help to improve the complaint system and respond to those customer demands which the system had not anticipated. An explanation might be sought concerning in which situations the complaint system itself becomes the seed of co-creation behaviour from company employees. 


\section{REFERENCES}

Anderson, J.C. \& Narus, J.A. (1990). A model of distributor firm and manufacturer firm working partnerships, Journal of Marketing, 54 (1), 42-58.

Armstrong, J.S. \& Overton, T.S. (1977). Estimating no response bias in mail survey, Journal of Marketing Research, 14, 396-403.

Barney, J. B. (2001). Resource-based theories of competitive advantage: A ten-year retrospective on the resource-based view, Journal of Management, 6, 643-650.

Bettencourt, L.A. \& Brown, S.W. (1997). Contact employees: Relationships among workplace fairness, job satisfaction and prosocial service behaviors, Journal of Retailing, 73(1), 39-61.

Blocker, C.P., Flint, D.J., Myers, M.B. \& Slater, S.F. (2011). Proactive customer orientation and its role for creating customer value in global markets, Journal of the Academy of Marketing Science, 39, 216-233.

Blodgett, J.G., Granbois, D.H. \& Walters, R.G. (1993). The effects of perceived justice on complainants' negative word-of-mouth behavior and repatronage intentions, Journal of Retailing, 69(4), 399-428.

Blodgett, J.G., Hill, D.J. \& Tax, S.S. (1997). The effects of distributive, procedural, and interactional justice on postcomplaint behavior, Journal of Retailing, 73(2), 185-210.

Breitsohl, J., Khammash, M. \& Griffiths, G. (2010). E-business complaint management: perceptions and perspectives of online credibility, Journal of Enterprise Information Management, 23(5), 653-660.

Burns, T. \& Stalker, G.M. (1961). The Management of Innovation. London: Tavistock.

Cameron, K.S. \& Quinn, R.E. (1999). Diagnosing and changing organizational culture: Based on the competing values framework. Addison-Wesley.

Chebat, J. C. \& Kollias, P. (2000). The Impact of empowerment on customer contact employees’ roles in service organizations, Journal of Service Research, 3(1), 66-81.

Chen, T., Ma, K., Bian, X., Zheng, C. \& Devlin, J. (2018). Is high recovery more effective than expected recovery in addressing service failure?-A moral judgment perspective, Journal of Business Research, 82, 19.

Conlon, D.E. \& Murray, N.M (1996). Customer perceptions of corporate responses to product complaints: the role of explanations, Academy of Management Journal, 39(4), 1040-1056. 
Crone, G., Carey, L. \& Dowling, P. (2003). Calling on compensation in Australian call centres, Journal of Management \& Organization, 9(3), 62-76.

Davidow, M. (2000). The bottom line impact of organizational responses to customer complaints, Journal of Hospitality \&Tourism Research, 24(4), 473-490.

Davidow, M. (2003). Organizational responses to customer complaints: what works and what doesn't, Journal of Service Research, 5(3), 225-250.

Day, G.S. (2011). Closing the marketing capabilities gap, Journal of Marketing, 75(4), 183-195.

Del Río-Lanza, A.B., Vázquez-Casielles, R. \& Díaz-Martín, A.M (2009). Satisfaction with service recovery: Perceived justice and emotional responses, Journal of Business Research, 62(8), 775-781.

Deshpande, R. \& Farley, J.U. (2004). Organizational culture, market orientation, innovativeness, and firm performance: an international research odyssey, International Journal of Research in Marketing, 21(1), 3-22.

Donoghue, S., Strydom, N., Andrews, L., Pentecost, R. \& Klerk, H.M. (2016). Differences between black and white South Africans in product failure attributions, anger and complaint behavior, International Journal of Consumer Studies, 40, 257-267.

Estelami, H. (2000). Competitive and procedural determinants of delight and disappointment in consumer complaint outcomes, Journal of Service Research, 2(3), 285-300.

Fornell, C. \& Larcker, D.F. (1981). Evaluating structural equation models with unobservable variables and measurement error, Journal of Marketing Research, 18(February), 39-50.

Fornell, C. \& Wernerfelt, B. (1988). A model for customer complaint management, Marketing Science, 7(3), 287-298.

Fuller, C.M., Simmering, M.J., Atinc, G., Atinc, Y. \& Babin, B.J. (2016). Common methods variance detection in business research, Journal of Business Research, 69, 3192-3198.

Gelbrich, K. \& Roschk, H. (2011). Do complainants appreciate overcompensation? A meta-analysis on the effect of simple compensation vs. overcompensation on post-complaint satisfaction, Marketing Letters, 22, 31-47.

Gielis, A.H. van der Heijden, Schepers, J.J.L., Nijssen, E.J. \& Ordanini, A. (2013). Don’t just fix it, make it better!. Using frontline service employees to improve recovery performance, Journal of the Academy Marketing Science, 41, 515-530 
Goodwin, C. \& Ross, I. (1992). Consumer responses to service failures: Influence of procedural and interactional fairness perceptions, Journal of Business Research, 25(2), 149-163.

Greenberg, J. (1990). Organizational justice: Yesterday, today, and tomorrow, Journal of Management, 16(2), 399-432.

Grinstein A. (2008). The relationships between market orientation and alternative strategic orientations, European Journal of Marketing, 42(1/2), 115-134.

Grönross, C. (1978). A service-orientated approach to marketing of services, European Journal of Marketing, 12(8), 588-601.

Hair, J.F., Hult, G.T.M., Ringle, C.M. \& Sarstedt, M. (2017). A Primer on Partial Least Squares Structural Equation Modeling (PLS-SEM). Second edition. Los Angeles: Sage.

Halbheer, D., Gärtner, D.L., Gerstner, E. \& Koenigsberg O. (2018). Optimizing service failure and damage control, International Journal of Research in Marketing, 35, 100-115.

Hart, C.W.L., Heskett, J.L. \& Sasser, W.E. Jr. (1990). The profitable art of service recovery, Harvard Business Review, 68(July/August), 148-156.

Harun, A., Rokonuzzaman, Md., Prybutok, G. \& Prybutok, V.R. (2018). How to influence consumer mindset: A perspective from service recovery, Journal of Retailing and Consumer Services, 24(May), 65-77.

Hazée, S., Van Vaerenbergh, Y. \& Armirotto, V. (2017). Co-creating service recovery after service failure: The role of brand equity, Journal of Business Research, 74, 101-109.

Heide, J.B. \& John, G. (1992). Do norms matter in marketing relationships?, Journal of Marketing, 56(April), $32-44$.

Heidenreich, S., Wittkowski, K., Handrich, M. \& Falk, T. (2015). The dark side of customer co-creation: Exploring the consequences of failed co-creation services, Journal of the Academy of Marketing Science, 43(3), 279-296.

Henseler, J., Ringle, C.M. \& Sarstedt, M. (2015). A new criterion for assessing discriminant validity in variancebased structural equation modeling, Journal of the Academy of Marketing Science, 43(1), 115-135.

Hoffman, K.D., Kelley, S.W. \& Rotalsky, H.M. (1995). Tracking service failures and employee recovery efforts, Journal of Services Marketing, 9(2), 49-61. 
Homburg, C. \& Fürst, A. (2005). How organizational complaint handling drives customer loyalty: An analysis of the mechanistic and the organic approach, Journal of Marketing, 69(July), 95-114.

Homburg, C. \& Fürst, A. (2007). See no evil, hear no evil, speak no evil: A study of defensive organizational behavior towards customer complaints, Journal of the Academy Marketing Science, 35, 523-536.

Homburg, C. \& Pflesser, C. (2000). A multiple-layer model of market-oriented organizational culture: Measurement issues and performance outcomes, Journal of Marketing Research, 37(November), 449-62.

Homburg, C., Fürst, A. \& Koschate, N. (2010). On the importance of complaint handling design: A multi-level analysis of the impact in specific complaint situations, Journal of the Academy Marketing Science, 38, 265287.

Hurley, R.F. \& Hult, G.T. (1998). Innovation, market orientation, and organizational learning: An integration and empirical examination, Journal of Marketing 62(3), 42-54.

Johnston, R. (2001). Linking complaint management to profit, International Journal of Service Industry Management, 12(1), 60-69.

Johnston, R. \& Mehra, S. (2002). Best-practice complaint management, Academy of Management Executive, 16(4), 145-154.

Kessler, S.R., Nixon, A.E. \& Nord, W.R. (2017). Examining organic and mechanistic structures: Do we know as much as we thought?, International Journal of Management Reviews,19, 531-555.

Kim, H. J., Hur, W.M., Moon, T.W. \& Jun, J.K. (2017). Is all support equal? The moderating effects of supervisor, coworker, and organizational support on the link between emotional labor and job performance, Business Research Quarterly, 20(2), 124-136.

Kirca, A.H., Jayachandran, S. \& Bearden, W.O. (2005). Market orientation: A meta-analytic review and assessment of its antecedents and impact on performance, Journal of Marketing, 69(2), 24-41.

Knox, G. \& Oest, R. van (2014). Customer complaints and recovery effectiveness: A customer base approach, Journal of Marketing, September, 78(5), 42-57.

Kohli, A.K. \& Jaworski, B.J. (1990). Market orientation: The construct, research propositions, and managerial implications, The Journal of Marketing, 54(April), 1-18.

Kotter, J. P. \& Heskett, J.L. (1992). Corporate Culture and Performance. New York: Free Press, 1992. 
Kumar, K., Jones, E., Venkatesan, R. \& Leon, R.P. (2011). Is market orientation a source of sustainable competitive advantage or simply the cost of competing?, Journal of Marketing, 75(January): 16-30.

Kwak, W.J. \& Jackson, C.L. (2015). Relationship building in empowering leadership processes: A test of mediation and moderation, Journal of Management \& Organization, 21(4), 369-387

Kwon, S. \& Jang, S.S. (2012). Effects of compensation for service recovery: From the equity theory perspective, International Journal of Hospitality Management, 31(4), 1235-1243.

La, K.V. \& Kandampully, J. (2004). Market oriented learning and customer value enhancement through service recovery management, Managing Service Quality, 14(5), 390-401.

Langerak, F., Hultink, E. J. \& Robben, H. S. J. (2004). The impact of market orientation, product advantage, and launch proficiency on new product performance and organizational performance, Journal of Product Innovation Management, 21(2), 79-94.

Lind, E.A. \& Tyler, T.R. (1988): The Social Psychology of Procedural Justice. New York: Plenum Press.

Lindblom, A. \& Olkkonen, R. (2006). Category management tactics: An analysis of manufacturers’ control, International Journal of Retail and Distribution Management, 34(6), 482-496.

Ma, L., Sun, B. \& Kekre, S. (2015). The squeaky wheel gets the grease-An empirical analysis of customer voice and firm intervention on Twitter. Marketing Science, 34(5), 627-645.

Maxham III, J.G. \& Netemeyer, R.G. (2003). Firms reap what they sow: The effects of shared values and perceived organizational justice on customers' evaluations of complaint handling, Journal of Marketing, 67(January), 46-62.

McCollough, M.A., Berry, L.L. \& Yadav, M.S. (2000). An empirical investigation of customer satisfaction after service failure and recovery, Journal of Service Research, 3(2), 121-137.

Narver, J.C. \& Slater, S.F. (1990). The effect of market orientation on business profitability, Journal of Marketing, 54(October), 20-35.

Narver, J.C., Slater, S.F. \& MacLachlan, D.L. (2004). Responsive and proactive market orientation, and new product success, Journal of Product Innovation Management, 21(5), 334-347.

Nsenduluka, E. \& Shee, H.K. (2009). Organisational and group antecedents of work group service innovativeness, Journal of Management \& Organization, 15(4), 438-451. 
Orsingher, C., Valentini, S. \& Angelis, M. de (2010). A meta-analysis of satisfaction with complaint handling in services, Journal of the Academy of Marketing Science, 38(2), 169-186.

Podsakoff, P.M. \& Organ, D.W. (1986). Self-reports in organizational research: Problems and prospects, Journal of Management, 12(4), 531-544.

Podsakoff, P.M., Mackenzie, S.B., Lee, J.Y. \& Podsakoff, J.O. (2003). Common method bias in behavioral research: A critical review of the literature and recommended remedies, Journal of Applied Psychology, 88(5), 879-903.

Ringle, C.M., Wende, S. \& Becker, J.M. (2015). SmartPLS 3. Bönningstedt: SmartPLS GmbH.

Santos-Vijande, M.L., Díaz-Martín, A.M., Suárez-Álvarez, L. \& Del Río-Lanza, A.B. (2013). An integrated service recovery system (ISRS): Influence on knowledge intensive business services performance, European Journal of Marketing, 47(5/6), 934-963.

Saxby, C.L., Tat, P.K. \& Johansen, J.T. (2000). Measuring consumer perceptions of procedural justice in a complaint context, Journal of Consumer Affairs, 34(2), 204-225.

Schein, E.H. 1992. Organizational Culture and Leadership, 2d ed. San Francisco: Jossey-Bass Publishers.

Schwartz, H. \& Davis, S.M. (1981). Matching corporate culture and business strategy, Organizational Dynamics, 10(1), 30-48.

Siguaw, J. A., Simpson, P.M. \& Enz, C.A. (2006). Conceptualizing innovation orientation: A framework for study and integration of innovation research, Journal of Product Innovation Management, 23(6), 556-574.

Smircich, L. (1983). Concepts of culture and organizational analysis, Administrative Science Quaterly, 28, 339358.

Smith, A.K. \& Bolton, R.N. (1998). An experimental investigation of customer reactions to service failure and recovery encounters: Paradox or peril?, Journal of Service Research, 1(1), 65-81.

Smith, A.K., Bolton, R.N. \& Wagner, J. (1999). A Model of Customer Satisfaction with Service Encounters Involving Failure and Recovery, Journal of Marketing Research, 36(August), 356-372.

Tax, S.S. \& Brown, S.W. (1998). Recovering and learning from service failure, Sloan Management Review, 40(1), $75-88$ 
Tax, S.S., Brown, S.W. \& Chandrashekaran, M. (1998). Customer evaluations of service complaint experiences: Implications for relationship marketing, Journal of Marketing, 62(April), 60-76.

Umashankar, N., Ward, M.K. \& Dahl, D.W. (2017). The Benefit of Becoming Friends: Complaining After Service Failures Leads Customers with Strong Ties to Increase Loyalty, Journal of Marketing, 81(6), 79-98.

Van Vaerenberg, Y. \& Orsingher, C. (2016). Service recovery: An integrative framework and research agenda, The Academy of Management Perspectives, 30(3), 328-346.

Vos, J.F.J., Huitema, G. B. \& Lange-Ros, E. De (2008). How organisations can learn from complaints, TQM Journal, 20(1), 8-17.

Webster, C. \& Sundaram, D.S. (1998). Service consumption criticality in failure recovery, Journal of Business Research, 41(February), 153-159.

Wirtz, J. \& Mattila, A.S. (2004). Consumer responses to compensation, speed of recovery and apology after a service failure, International Journal of Service Industry Management, 15(2), 150-166.

Yilmaz, C., Varnali, K. \& Kasnakoglu, B.T. (2016). How do firms benefit from customer complaints?, Journal of Business Research, 69 (2), 944-955. 
TABLE 1

Population and sample distribution

\begin{tabular}{|c|c|c|c|c|c|c|}
\hline Industry (NACE) & $\begin{array}{c}\text { Number of } \\
\text { companies } \\
\text { in the } \\
\text { population } \\
(\%)\end{array}$ & $\begin{array}{c}\text { Number of } \\
\text { companies } \\
\text { in the } \\
\text { sample } \\
(\%)\end{array}$ & $\begin{array}{c}\text { Proportion } \\
\text { test }\end{array}$ & \begin{tabular}{|c|} 
Average \\
employee \\
number of \\
companies in \\
the population \\
(std. dev.) \\
\end{tabular} & \begin{tabular}{|c} 
Average \\
employee \\
number of \\
companies in \\
the sample \\
(std. dev.) \\
\end{tabular} & $\begin{array}{c}\text { Means } \\
\text { difference } \\
\text { test }\end{array}$ \\
\hline Food, drink and tobacco industry $(10,11,12)$ & $\begin{array}{c}599 \\
(23.62 \%)\end{array}$ & $\begin{array}{c}30 \\
(21.43 \%)\end{array}$ & -.63 & $\begin{array}{c}233 \\
(546)\end{array}$ & $\begin{array}{c}247 \\
(324)\end{array}$ & .30 \\
\hline $\begin{array}{l}\text { Textile, clothing, leather and footwear industry }(13,14 \text {, } \\
15)\end{array}$ & $\begin{array}{c}215 \\
(8.48 \%)\end{array}$ & $\begin{array}{c}12 \\
(8.57 \%)\end{array}$ & .04 & $\begin{array}{c}146 \\
(211)\end{array}$ & $\begin{array}{c}195 \\
(372)\end{array}$ & .80 \\
\hline $\begin{array}{l}\text { Paper, edition, graphic arts and reproduction industry (17, } \\
\text { 18) }\end{array}$ & $\begin{array}{c}235 \\
(9.27 \%) \\
\end{array}$ & $\begin{array}{c}19 \\
(13.57 \%) \\
\end{array}$ & 1.49 & $\begin{array}{c}142 \\
(154) \\
\end{array}$ & $\begin{array}{c}141 \\
(177) \\
\end{array}$ & -.03 \\
\hline Chemical, rubber and plastics industry $(20,21,22)$ & $\begin{array}{c}747 \\
(29.46 \%) \\
\end{array}$ & $\begin{array}{c}32 \\
(22.86 \%) \\
\end{array}$ & -1.86 & $\begin{array}{c}232 \\
(507) \\
\end{array}$ & $\begin{array}{c}490 * \\
(1575) \\
\end{array}$ & $2.64^{*}$ \\
\hline $\begin{array}{l}\text { Electrical, electronic and optical material and equipment } \\
\text { industry }(26,27)\end{array}$ & $\begin{array}{c}288 \\
(11.36 \%) \\
\end{array}$ & $\begin{array}{c}20 \\
(14.29 \%) \\
\end{array}$ & .99 & $\begin{array}{c}251 \\
(557) \\
\end{array}$ & $\begin{array}{c}158 \\
(130) \\
\end{array}$ & -.75 \\
\hline Transportation Equipment (29) & $\begin{array}{c}263 \\
(10.37 \%) \\
\end{array}$ & $\begin{array}{c}13 \\
(9.29 \%) \\
\end{array}$ & -.44 & $\begin{array}{c}497 \\
(1.356) \\
\end{array}$ & $\begin{array}{c}204 \\
(208) \\
\end{array}$ & -.84 \\
\hline Other manufacturing industries $(31,32)$ & $\begin{array}{c}189 \\
(7.45 \%)\end{array}$ & $\begin{array}{c}14 \\
(10.00 \%) \\
\end{array}$ & 1.00 & $\begin{array}{c}145 \\
(185) \\
\end{array}$ & $\begin{array}{c}241 \\
(281) \\
\end{array}$ & 1.27 \\
\hline Total & $\begin{array}{c}2536 \\
(100.00 \%)\end{array}$ & $\begin{array}{c}140 \\
(100.00 \%) \\
\end{array}$ & & $\begin{array}{c}240 \\
(624)\end{array}$ & $\begin{array}{c}262 \\
(771)\end{array}$ & .39 \\
\hline
\end{tabular}

* Significant difference. 
TABLE 2

Indicators for Measurement Model Constructs

\begin{tabular}{|c|c|c|c|c|c|}
\hline Construct & Indicators & Mean & $\begin{array}{c}\text { Stand. } \\
\text { Dev. }\end{array}$ & Weights & Loadings \\
\hline 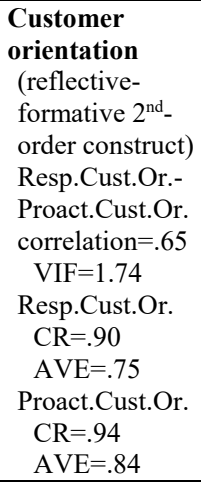 & $\begin{array}{l}\text { Responsive customer orientation } \\
\text { We constantly measure consumer satisfaction. } \\
\text { We respond rapidly to customers' needs and wishes. } \\
\text { In the event of customer dissatisfaction or complaints, we take steps to correct it as soon } \\
\text { as possible. } \\
\text { Proactive customer orientation } \\
\text { We think of future customer requirements. } \\
\text { We include solutions to problems customers are yet to experience. } \\
\text { We try to anticipate customers' wishes. }\end{array}$ & $\begin{array}{l}5.30 \\
5.86 \\
6.12\end{array}$ & $\begin{array}{l}1.32 \\
1.40 \\
1.38\end{array}$ & $\begin{array}{l}.49^{* *} \\
.39^{* *} \\
.41^{* *} \\
.36^{* *} \\
\\
.61^{* *} \\
.38^{* *} \\
.35^{* *} \\
.36^{* *}\end{array}$ & $\begin{array}{l}.81^{* *} \\
.93^{* *} \\
.85^{* *}\end{array}$ \\
\hline $\begin{array}{l}\begin{array}{c}\text { Innovation } \\
\text { orientation } \\
\mathrm{CR}=.93 \\
\mathrm{AVE}=.77\end{array}\end{array}$ & $\begin{array}{l}\text { We constantly renew the list of new or superior products } \\
\text { The company invests a large amount of resources in developing new products. } \\
\text { Product innovation is one of the company's main activities. } \\
\text { A large percentage of our sales comes from products introduced in the last two years. }\end{array}$ & $\begin{array}{l}5.16 \\
5.04 \\
5.00 \\
4.41\end{array}$ & $\begin{array}{l}1.59 \\
1.63 \\
1.70 \\
1.65\end{array}$ & $\begin{array}{l}.29^{* *} \\
.31^{* *} \\
.32^{* *} \\
.21^{* *}\end{array}$ & $\begin{array}{l}.90^{* *} \\
.91^{* *} \\
.93^{* *} \\
.75^{* *}\end{array}$ \\
\hline $\begin{array}{c}\begin{array}{c}\text { Defensive } \\
\text { objectives } \\
C R=.91 \\
\mathrm{AVE}=.78\end{array} \\
\end{array}$ & $\begin{array}{l}\text { To avoid customer loss. } \\
\text { To restore satisfaction. } \\
\text { To strengthen customer loyalty. }\end{array}$ & $\begin{array}{l}6.40 \\
6.46 \\
6.46\end{array}$ & $\begin{array}{l}.98 \\
.87 \\
.92\end{array}$ & $\begin{array}{l}.27^{* *} \\
.41^{* *} \\
.43^{* *}\end{array}$ & $\begin{array}{l}.70^{* *} \\
.96^{* *} \\
.95^{* *}\end{array}$ \\
\hline $\begin{array}{l}\text { Improvement } \\
\text { objectives } \\
\mathrm{CR}=.91 \\
\mathrm{AVE}=.78 \\
\end{array}$ & $\begin{array}{l}\text { To use complaints as improvement opportunities for company management. } \\
\text { To get information to improve products and services in general. } \\
\text { To get information to improve products launched in the last two years. }\end{array}$ & $\begin{array}{l}6.03 \\
5.86 \\
5.29\end{array}$ & $\begin{array}{l}1.25 \\
1.44 \\
1.82\end{array}$ & $\begin{array}{l}.46^{* *} \\
.36^{* *} \\
.30^{* *}\end{array}$ & $\begin{array}{l}.90^{* *} \\
.93^{* *} \\
.81^{* *}\end{array}$ \\
\hline $\begin{array}{l}\text { Facilitation } \\
\text { Máx. corr. }=.56 \\
\text { Máx. } \mathrm{VIF}=1.63\end{array}$ & $\begin{array}{l}\text { We provide the customer with various channels for receiving complaints. } \\
\text { Some of the channels are available } 24 \text { hours a day. } \\
\text { We inform customers about where, how and to whom they should make the complaint. }\end{array}$ & $\begin{array}{l}5.14 \\
4.61 \\
5.21\end{array}$ & $\begin{array}{l}1.69 \\
2.46 \\
1.71\end{array}$ & $\begin{array}{l}.63^{* *} \\
.17 \\
.41^{*}\end{array}$ & $\begin{array}{l}.92^{* *} \\
.64^{* *} \\
.78^{* *}\end{array}$ \\
\hline $\begin{array}{l}\text { Processing } \\
\text { protocol } \\
\text { Máx. corr. }=.70 \\
\text { Máx. VIF= } 2.25\end{array}$ & $\begin{array}{l}\text { We quickly confirm to customers when we have received the complaint. } \\
\text { All complaints, written or verbal, are recorded in the computer system. } \\
\text { All the complaints are categorized and classified according to their origin and the severity } \\
\text { of the problem. } \\
\text { As soon as a complaint is received, we assign a person responsible for handling it. } \\
\text { Complaints are rapidly commented on and dealt with. }\end{array}$ & $\begin{array}{l}5.71 \\
5.84 \\
5.27 \\
6.04 \\
6.12 \\
\end{array}$ & $\begin{array}{l}1.34 \\
1.53 \\
1.73 \\
1.28 \\
1.15 \\
\end{array}$ & $\begin{array}{l}.19 \\
.23 \\
.07 \\
-.02 \\
.75^{* *} \\
\end{array}$ & $\begin{array}{l}.61^{* *} \\
.64^{* *} \\
.53^{* *} \\
.67^{* *} \\
.95^{* *} \\
\end{array}$ \\
\hline $\begin{array}{l}\text { Customer } \\
\text { participation in } \\
\text { the process } \\
\mathrm{CR}=.97 \\
\mathrm{AVE}=.93\end{array}$ & $\begin{array}{l}\text { We allow the customer to explain the complaint. } \\
\text { We give customers the chance to set out all the details. } \\
\text { We listen to their point of view about their problem. }\end{array}$ & $\begin{array}{l}6.24 \\
6.34 \\
6.38\end{array}$ & $\begin{array}{l}1.03 \\
.98 \\
.95\end{array}$ & $\begin{array}{l}.37^{* *} \\
.36^{* *} \\
.31^{* *}\end{array}$ & $\begin{array}{l}.95^{* *} \\
.99^{* *} \\
.95^{* *}\end{array}$ \\
\hline $\begin{array}{l}\text { Customer } \\
\text { participation in } \\
\text { the solution } \\
\mathrm{CR}=.90 \\
\mathrm{AVE}=.76\end{array}$ & $\begin{array}{l}\text { When providing the solution, we are concerned with customer requirements. } \\
\text { We ask the customer for possible solutions. } \\
\text { Company and customer work together to find a solution to the complaint. }\end{array}$ & $\begin{array}{l}6.05 \\
5.61 \\
5.56\end{array}$ & $\begin{array}{l}1.13 \\
1.46 \\
1.47\end{array}$ & $\begin{array}{l}.51^{* *} \\
.31^{* *} \\
.32^{* *}\end{array}$ & $\begin{array}{l}.89^{* *} \\
.91^{* *} \\
.80^{* *}\end{array}$ \\
\hline $\begin{array}{l}\text { Interpersonal } \\
\text { treatment } \\
\mathrm{CR}=.92 \\
\mathrm{AVE}=.80\end{array}$ & $\begin{array}{l}\text { The frontline employee displays polite treatment with the customer when the latter } \\
\text { formulates complaints. } \\
\text { Employees are very interested in the customer's problem. } \\
\text { Employees who are responsible for complaint management have empathy skills with the } \\
\text { customer. }\end{array}$ & $\begin{array}{l}6.34 \\
6.35 \\
6.20\end{array}$ & $\begin{array}{l}.77 \\
.83 \\
.79\end{array}$ & $\begin{array}{l}.40^{* *} \\
.42^{* *} \\
.30^{* *}\end{array}$ & $\begin{array}{l}.91^{* *} \\
.92^{* *} \\
.85^{* *}\end{array}$ \\
\hline $\begin{array}{l}\text { Explanation } \\
\mathrm{CR}=.94 \\
\mathrm{AVE}=.88\end{array}$ & $\begin{array}{l}\text { We provide our customer with a reasonable explanation about the causes of the problem. } \\
\text { We provide a precise answer to all the questions raised in the customer's complaint. }\end{array}$ & $\begin{array}{l}6.21 \\
6.19\end{array}$ & $\begin{array}{l}.90 \\
.84\end{array}$ & $\begin{array}{l}.50^{* *} \\
.57^{* *}\end{array}$ & $.93^{* *}$ \\
\hline $\begin{array}{l}\text { Apology } \\
\mathrm{CR}=.87 \\
\mathrm{AVE}=.69\end{array}$ & $\begin{array}{l}\text { We always admit our fault to the customer if the complaint is reasonable. } \\
\text { If any failure occurs, we admit our responsibility and we let the customer know about it. } \\
\text { Apart from solving the problem, we always apologise to our customer. }\end{array}$ & $\begin{array}{l}6.05 \\
6.17 \\
6.05 \\
\end{array}$ & $\begin{array}{l}1.18 \\
1.06 \\
1.34\end{array}$ & $\begin{array}{l}.45^{* *} \\
.45^{* *} \\
.30^{* *}\end{array}$ & $\begin{array}{l}.88^{* *} \\
.89^{* *} \\
.70^{* *}\end{array}$ \\
\hline $\begin{array}{l}\text { Redress } \\
\mathrm{CR}=.87 \\
\mathrm{AVE}=.76\end{array}$ & $\begin{array}{l}\text { Beyond the solution, we offer our customer a direct financial redress. } \\
\text { Beyond the solution, we offer our customer an indirect financial redress. }\end{array}$ & $\begin{array}{l}4.04 \\
2.88\end{array}$ & $\begin{array}{l}1.93 \\
1.97\end{array}$ & $\begin{array}{l}.69^{* *} \\
.43^{* *}\end{array}$ & $\begin{array}{l}.93^{* *} \\
.81^{* *}\end{array}$ \\
\hline $\begin{array}{l}\text { Training } \\
\mathrm{CR}=.94 \\
\mathrm{AVE}=.85\end{array}$ & $\begin{array}{l}\text { We train employees responsible for complaint handling properly. } \\
\text { The training received allows them to manage complaints effectively. } \\
\text { Employees are taught about values and attitudes for effective complaint handling. }\end{array}$ & $\begin{array}{l}5.58 \\
5.55 \\
5.78\end{array}$ & $\begin{array}{l}1.31 \\
1.37 \\
1.08\end{array}$ & $\begin{array}{l}.35^{* *} \\
.34^{* *} \\
.39^{* *}\end{array}$ & $\begin{array}{l}.93^{* *} \\
.93^{* *} \\
.90^{* *}\end{array}$ \\
\hline
\end{tabular}




\begin{tabular}{|c|c|c|c|c|c|}
\hline $\begin{array}{l}\text { Empowerment } \\
\mathrm{CR}=.89 \\
\mathrm{AVE}=.72\end{array}$ & $\begin{array}{l}\text { We allow employees to reach decisions on solving the problem. } \\
\text { Employees are provided with authority to manage their contact with the customer and } \\
\text { how to deal with a complaint. } \\
\text { We rely fully on the great work of our employees to solve customers' complaints. }\end{array}$ & $\begin{array}{l}5.58 \\
4.98 \\
5.69\end{array}$ & $\begin{array}{l}1.22 \\
1.58 \\
1.09\end{array}$ & $\begin{array}{l}.42^{* *} \\
.32^{* *} \\
.43^{* *}\end{array}$ & $\begin{array}{l}.86^{* *} \\
.80^{* *} \\
.88^{* *}\end{array}$ \\
\hline $\begin{array}{l}\text { Extra-role } \\
\text { behaviour } \\
\mathrm{CR}=.90 \\
\mathrm{AVE}=.75\end{array}$ & $\begin{array}{l}\text { Generally, employees go further than is required in their job. } \\
\text { They make an even greater effort to solve complaints. } \\
\text { They often present creative solutions to customers' problems. }\end{array}$ & $\begin{array}{l}5.15 \\
5.23 \\
5.36\end{array}$ & $\begin{array}{l}1.42 \\
1.43 \\
1.31\end{array}$ & $\begin{array}{l}.39^{* *} \\
.43^{* *} \\
.33^{* *}\end{array}$ & $\begin{array}{l}.93^{* *} \\
.94^{* *} \\
.72^{* *}\end{array}$ \\
\hline
\end{tabular}

Note: The weights appear with a paler font colour to indicate that in the case of the reflective indicators it is not the weight but the loading which is the value being examined.

Level of significance: $* * \mathrm{p}<.01 ; * \mathrm{p}<.05$ (one-tailed test). 
TABLE 3

Correlation matrix and discriminant validity

\begin{tabular}{|c|c|c|c|c|c|c|c|c|c|c|c|c|c|c|c|}
\hline & 1 & 2 & 3 & 4 & 5 & 6 & 7 & 8 & 9 & 10 & 11 & 12 & 13 & 14 & 15 \\
\hline 1. Customer orientation & n.a. & .43 & .34 & .45 & .48 & .44 & .49 & n.a. & n.a. & .47 & .49 & .46 & .49 & .57 & .19 \\
\hline 2. Innovation orientation & .41 & .88 & .23 & .51 & .20 & .36 & .33 & n.a. & n.a. & .18 & .25 & .23 & .13 & .34 & .13 \\
\hline 3. Defensive objectives & .31 & .22 & .88 & .32 & .26 & .30 & .28 & n.a. & n.a. & .44 & .34 & .51 & .46 & .44 & .13 \\
\hline 4. Improvement objectives & .41 & .44 & .30 & .88 & .41 & .41 & .46 & n.a. & n.a. & .34 & .40 & .34 & .39 & .65 & .28 \\
\hline 5. Training & .44 & .19 & .24 & .38 & .92 & .60 & .44 & n.a. & n.a. & .42 & .41 & .46 & .58 & .45 & .21 \\
\hline 6. Empowerment & .38 & .31 & .25 & .36 & .52 & .85 & .55 & n.a. & n.a. & .44 & .43 & .37 & .48 & .48 & .30 \\
\hline 7. Extra-role behaviour & .42 & .29 & .24 & .40 & .39 & .45 & .87 & n.a. & n.a. & .49 & .44 & .48 & .48 & .50 & .13 \\
\hline 8. Facilitation & .30 & .30 & .18 & .49 & .23 & .28 & .43 & n.a. & n.a. & n.a. & n.a. & n.a. & n.a. & n.a. & n.a. \\
\hline 9. Processing protocol & .47 & .17 & .44 & .39 & .33 & .27 & .30 & .45 & n.a. & n.a. & n.a. & n.a. & n.a. & n.a. & n.a. \\
\hline 10. Customer participation in process & .44 & .17 & .40 & .33 & .40 & .40 & .38 & .53 & .68 & .96 & .63 & .70 & .66 & .71 & .07 \\
\hline 11. Customer participation in solution & .44 & .25 & .32 & .36 & .37 & .38 & .40 & .38 & .52 & .58 & .87 & .50 & .56 & .52 & .16 \\
\hline 12. Interpersonal treatment & .40 & .21 & .46 & .31 & .41 & .32 & .41 & .36 & .56 & .65 & .45 & .90 & .82 & .72 & .08 \\
\hline 13. Explanation & .43 & .12 & .40 & .36 & .52 & .41 & .41 & .34 & .56 & .61 & .49 & .72 & .94 & .67 & .17 \\
\hline 14. Apology & .47 & .29 & .37 & .55 & .39 & .40 & .40 & .49 & .62 & .62 & .44 & .59 & .56 & .83 & .29 \\
\hline 15. Redress & .17 & .10 & .11 & .23 & .18 & .21 & .10 & .20 & .05 & -.05 & .13 & .07 & .14 & .22 & .87 \\
\hline
\end{tabular}

Note: The elements below the diagonal correspond to the correlations between each pair of constructs. On the diagonal is the square root of the AVE. The elements above the diagonal correspond to the HTMT ratio for each pair of constructs (Henseler et al., 2015).

n.a.: not applicable to formative constructs. 
TABLE 4

Model standardized coefficients

Relationships

Path coefficients

\begin{tabular}{clc} 
Effect of company culture on the objectives of the complaint management system $\left(\mathbf{H}_{\mathbf{I}}\right)$ \\
\hline $\mathrm{H}_{\mathrm{I} .1 \mathrm{a}}$ & Customer orientation $\rightarrow$ Defensive objectives & $.31^{* *}$ \\
$\mathrm{H}_{\mathrm{I} .1 \mathrm{~b}}$ & Customer orientation $\rightarrow$ Improvement objectives & $.27^{* *}$ \\
$\mathrm{H}_{\mathrm{I} .2}$ & Innovation orientation $\rightarrow$ Improvement objectives & $.33^{* *}$ \\
\hline
\end{tabular}

Effect of the complaint management system objectives on the mechanistic approach $\left(\mathrm{H}_{\text {II }}\right)$

\begin{tabular}{|c|c|c|}
\hline HII.1a & Defensive objectives $\rightarrow$ Facilitation & .04 \\
\hline $\mathrm{H}_{\text {II. } .1 \mathrm{~b}}$ & Defensive objectives $\rightarrow$ Processing protocol & $.36^{* *}$ \\
\hline $\mathrm{H}_{\text {II.1c }}$ & Defensive objectives $\rightarrow$ Customer participation in process & $.33^{* *}$ \\
\hline HII.1d & Defensive objectives $\rightarrow$ Customer participation in solution & $.24^{* *}$ \\
\hline $\mathrm{H}_{\text {II.le }}$ & Defensive objectives $\rightarrow$ Interpersonal treatment & $.41^{* *}$ \\
\hline $\mathrm{H}_{\text {II. } .1 \mathrm{f}}$ & Defensive objectives $\rightarrow$ Explanation & $.32^{* *}$ \\
\hline HII.lg & Defensive objectives $\rightarrow$ Apology & $.22^{* *}$ \\
\hline $\mathrm{H}_{\text {II. } . \mathrm{h}}$ & Defensive objectives $\rightarrow$ Redress & .04 \\
\hline $\mathrm{H}_{\text {II.2a }}$ & Improvement objectives $\rightarrow$ Facilitation & $.47^{* *}$ \\
\hline $\mathrm{H}_{\text {II. } 2 \mathrm{~b}}$ & Improvement objectives $\rightarrow$ Processing protocol & $.29^{* *}$ \\
\hline $\mathrm{H}_{\mathrm{II} .2 \mathrm{c}}$ & Improvement objectives $\rightarrow$ Customer participation in process & $.23^{* *}$ \\
\hline $\mathrm{H}_{\mathrm{III} .2 \mathrm{~d}}$ & Improvement objectives $\rightarrow$ Customer participation in solution & $.29^{* *}$ \\
\hline HII.2e & Improvement objectives $\rightarrow$ Interpersonal treatment & $.19^{*}$ \\
\hline $\mathrm{H}_{\text {II. } 2 \mathrm{f}}$ & Improvement objectives $\rightarrow$ Explanation & $.26^{* *}$ \\
\hline $\mathrm{H}_{\text {II. } 2 \mathrm{~g}}$ & Improvement objectives $\rightarrow$ Apology & $.48^{* *}$ \\
\hline $\mathrm{H}_{\text {II. } 2 \mathrm{~h}}$ & Improvement objectives $\rightarrow$ Redress & $.21^{* *}$ \\
\hline
\end{tabular}

Effect of the complaint management system objectives on the organic approach $\left(\mathrm{H}_{\text {III }}\right)$

\begin{tabular}{lll}
$\mathrm{H}_{\text {III.1a }}$ & Defensive objectives $\rightarrow$ Training & .07 \\
$\mathrm{H}_{\text {III.1b }}$ & Defensive objectives $\rightarrow$ Empowerment & .10 \\
$\mathrm{H}_{\text {III.1c }}$ & Defensive objectives $\rightarrow$ Extra-role behaviour & .07 \\
$\mathrm{H}_{\text {III.2a }}$ & Improvement objectives $\rightarrow$ Training & $.25^{* *}$ \\
$\mathrm{H}_{\text {III.2b }}$ & Improvement objectives $\rightarrow$ Empowerment & $.19^{*}$ \\
$\mathrm{H}_{\text {III.2c }}$ & Improvement objectives $\rightarrow$ Extra-role behaviour & $.25^{* *}$ \\
\hline
\end{tabular}

Effect of company culture on the organic approach (Hiv)

\begin{tabular}{llc} 
HIV.1a & Customer orientation $\rightarrow$ Training & $.35^{* *}$ \\
HIV.1b $^{*}$ & Customer orientation $\rightarrow$ Empowerment & $.22^{* *}$ \\
H IV.1c & Customer orientation $\rightarrow$ Extra-role behaviour & $.28^{* *}$ \\
HIV.2a $_{\text {Innovation orientation } \rightarrow \text { Training }}$ & -.07 \\
H $_{\text {IV.2b }}$ & Innovation orientation $\rightarrow$ Empowerment & .11 \\
HIV.2c & Innovation orientation $\rightarrow$ Extra-role behaviour & .05 \\
\hline
\end{tabular}

Effect of customer orientation on innovation orientation

\begin{tabular}{|c|c|}
\hline Customer orientation $\rightarrow$ Innovation orientation & $.41^{* *}$ \\
\hline $\mathrm{R}^{2}$ of Innovation orientation & .164 \\
\hline $\mathrm{R}^{2}$ of Defensive objectives & .096 \\
\hline $\mathrm{R}^{2}$ of Improvement objectives & .253 \\
\hline $\mathrm{R}^{2}$ of Facilitation & .237 \\
\hline $\mathrm{R}^{2}$ of Processing protocol & .271 \\
\hline $\mathrm{R}^{2}$ of Customer participation in process & .209 \\
\hline $\mathrm{R}^{2}$ of Customer participation in solution & .182 \\
\hline $\mathrm{R}^{2}$ of Interpersonal treatment & .245 \\
\hline $\mathrm{R}^{2}$ of Explanation & .219 \\
\hline $\mathrm{R}^{2}$ of Apology & .348 \\
\hline $\mathrm{R}^{2}$ of Redress & .053 \\
\hline
\end{tabular}


Relationships

Path coefficients

$\mathrm{R}^{2}$ of Training $\quad .251$

$\mathrm{R}^{2}$ of Empowerment .215

$\mathrm{R}^{2}$ of Extra-role behaviour .249

Level of significance: ${ }^{* *} \mathrm{p}<.01 ;{ }^{*} \mathrm{p}<.05$ (one-tailed test) 
FIGURE 1

Proposed model

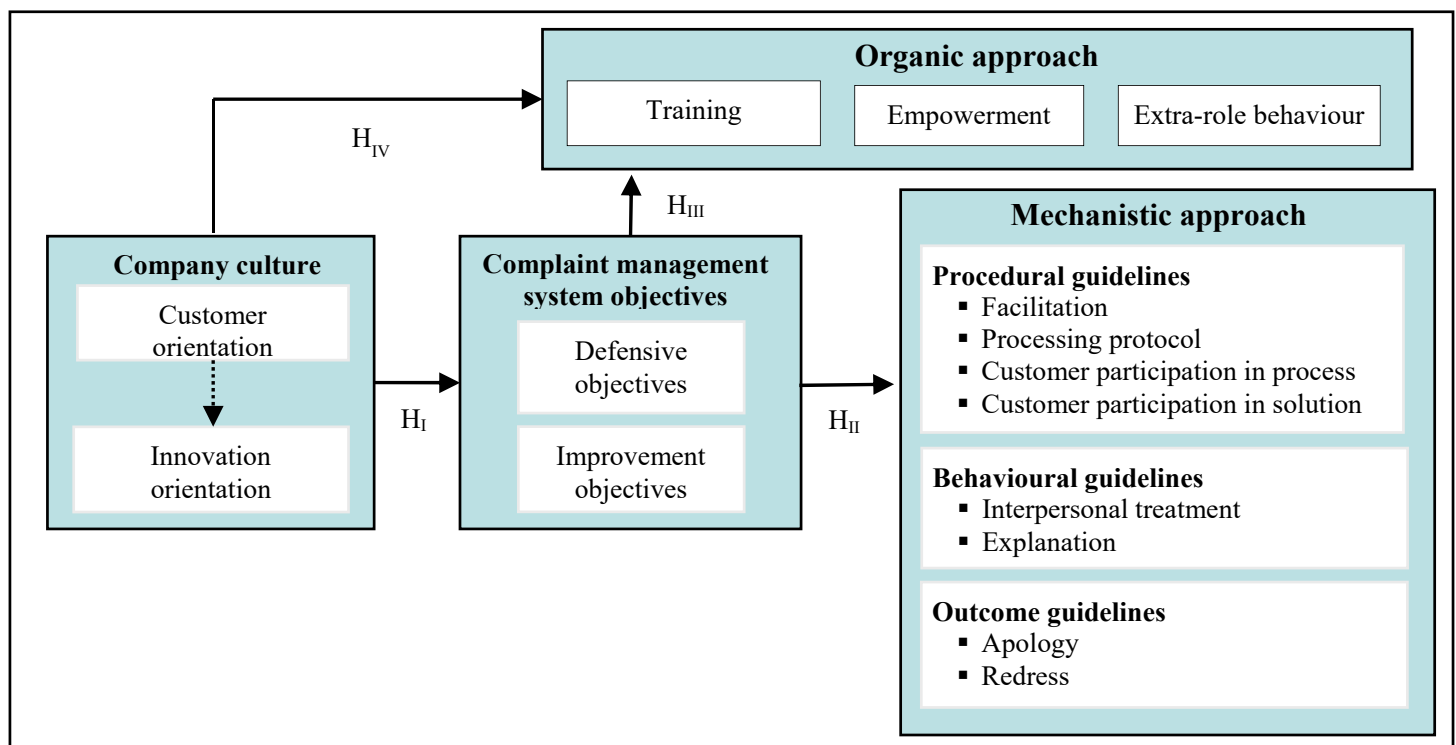

Adapted from Tax et al. (1998), Davidow (2003), Maxham and Netemeyer (2003), Homburg and Fürst (2005) and Homburg et al. (2010). 
FIGURE 2

Summary of empirical findings

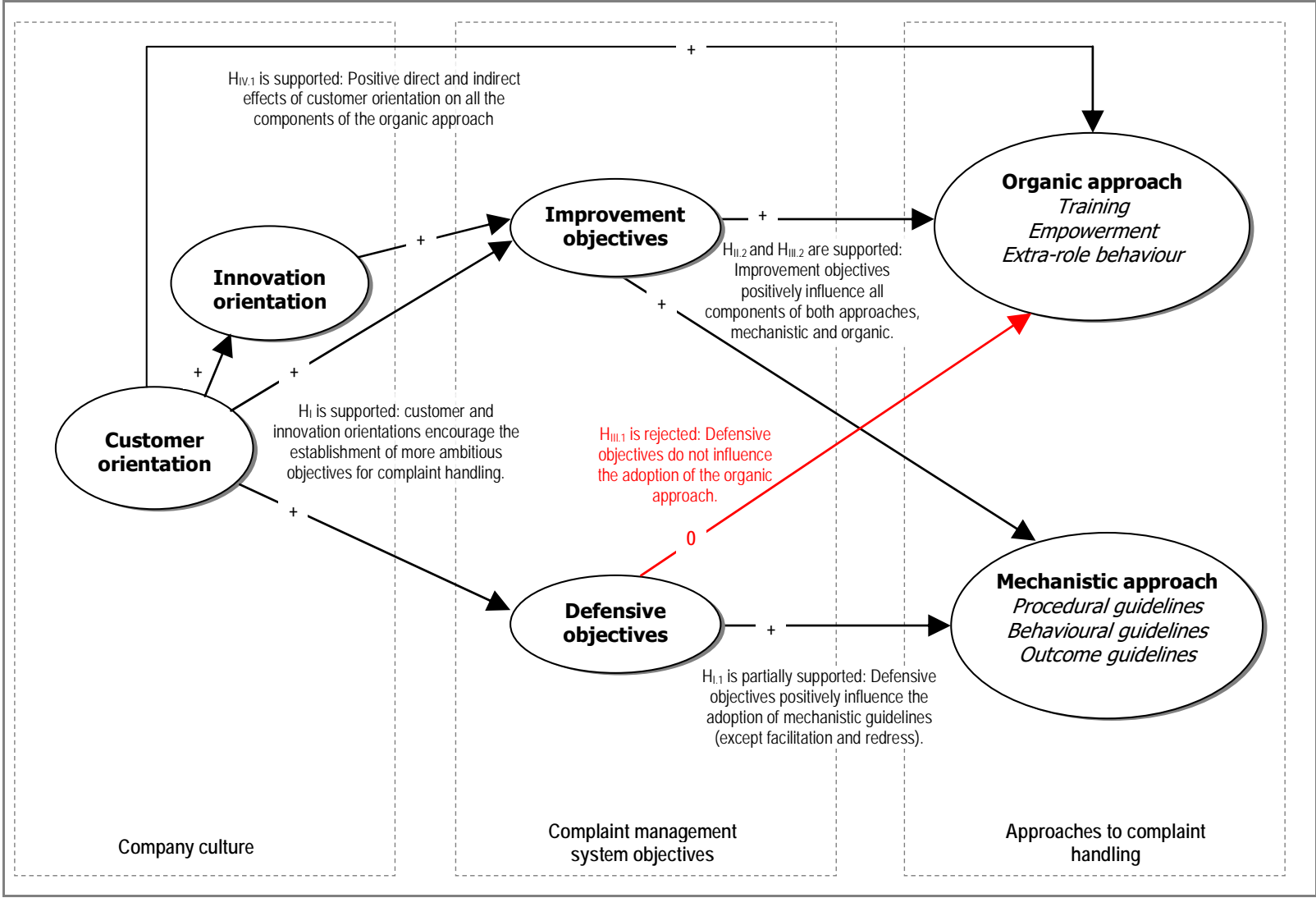

